\title{
Overview of 1-Methylcyclopropene Trials and Uses for Edible Horticultural Crops
}

\author{
Christopher B. Watkins ${ }^{1}$ \\ Department of Horticulture, Cornell University, 127 Plant Sciences Building, Ithaca, NY 14853-5908 \\ Additional index words. 1-methylcyclopropene, SmartFresh, ripening, senescence, physiological disorders, disease, \\ horticultural industries, technology
}

\begin{abstract}
The inhibitor of ethylene perception, 1-methylcyclopropene (1-MCP), is the basis of a new technology that is increasingly being used to improve storage potential and maintain quality of fruit and vegetables. 1-MCP is registered for use on a number of crops, including apple, apricot, avocado, banana, broccoli, kiwifruit, pear, mango, melon, peach, nectarine, persimmon, plum, and tomato. The registered crop is often specific to country. The effects of 1-MCP on quality of these crops, as well as its effects on physiological disorders and pathological diseases, are reviewed. Most available literature on 1-MCP has focused on laboratory-based trials and little information exists about its effects on product quality at the commercial level. The apple is the most significant exception, being the first crop for which 1-MCP was used commercially and extensively around the world. The apple is a crop for which limited ripening after harvest is desirable. For many other fruit, successful commercialization of 1-MCP will require an appropriate balance between 1-MCP concentrations and exposure periods that will delay but not inhibit ripening. The effects of preharvest factors, cultivar, maturity, and postharvest practices are complex and will impact commercial success of 1-MCP-based technology. For leafy or nonfruit vegetables, the advantages of 1-MCP may only be apparent under abusive conditions such as high temperatures and exogenous ethylene exposure. Finally, commercial utilization of 1-MCP-based technology will be a function of the cost of its application relative to its benefits for each product.
\end{abstract}

The recent registration of 1-methylcyclopropene (1-MCP) to inhibit ethylene perception in horticultural products has resulted in an exciting era for postharvest scientists. 1-MCP is being used not only as a tool to increase understanding of the involvement of ethylene in ripening and senescence processes, but also as the basis of a new technology for horticultural industries. However, although control of ethylene production and action in storage and handling is a major emphasis in storage and transport of fruit, vegetables, and ornamental products (Saltveit, 1999; Watkins, 2002), commercialization of 1-MCP is not trivial. The research available so far indicates that just like any traditional technology, such as low temperature and controlled atmosphere (CA) storage (Watkins and Ekman, 2005), effects of 1-MCP on product quality can be variable (Blankenship and Dole, 2003; Watkins, 2006). In addition to the need to understand how to apply the chemical in such a way that desirable effects on product quality are obtained, identification of how the technology can be incorporated into present handling systems to obtain these benefits is of equal importance.

\section{THE CONTEXT-A NEW ERA FOR POSTHARVEST RESEARCH}

Extensive literature about the effects of 1-MCP on fruit, vegetables, and ornamental products exists, and by 2007, results for over 50 fruit and vegetables, both whole

\footnotetext{
The support of the New York Apple Research and Development Program, AgroFresh Inc., and Cornell University Agricultural Experiment Station federal formula funds, Project No. NE-1018 is acknowledged.

${ }^{1}$ To whom correspondence should be addressed; e-mail cbw3@cornell.edu
}

and fresh-cut, as well as ornamental products, were available (Watkins and Miller, 2006). Despite this literature, however, relatively little information concerning commercial aspects of its use is available. The exception to this, at least partly, is the apple, for which 1-MCP-based technology is available throughout the world. The reasons for limited public information on commercial aspects of 1-MCP use result from at least two factors:

1. 1-MCP is still a new product for edible horticultural crops, and registration for its commercial use is still ongoing in several countries. Commercial use of 1-MCP-based technologies for apple was launched as recently as 2002 in Chile and Argentina and 2003 in New Zealand, South Africa, and the United States, and commercial testing of 1-MCP for many other horticultural products is ongoing. Thus, issues that identify strengths and weaknesses of the technology continue to be under investigation. Results on commercialization of other products are likely to be available in the future.

2. 1-MCP is being used on 16 horticultural products, but much commercially relevant research on its effects is proprietary. For example, research using 1-MCP to increase potential for shipping longer distances or increasing market share of various fruit is being undertaken around the world under confidentiality agreements. 1MCP commercialization represents a model for development of future technologies that represents a deviation from the classic model of "proof of concept" research by universities and research institutes followed by prolonged uptake by horticultural industries. 1-MCP research is patentholder-driven by a company with extensive in-house research capacity that is strategically investing in research internationally with both public and private research entities. In some respects, this situation parallels the situation with fresh-cut industries in which protection of proprietary information and timeliness of obtaining results is critical, and public research is used only as required to investigate longerterm problems.

A related and interesting factor about 1-MCP-based technology is that commercial application of 1-MCP, at least for apples in the United States, is made only by AgroFresh-related companies. Storage operators who have traditionally applied postharvest treatments themselves now arrange for the applications to be made on their behalf.

An indication of the perceived priorities for commercialization may lie with the registration profiles for horticultural products in various countries (Table 1). This list reflects commodities of specific interest to individual countries as well as products in which perceived benefits are recognized. There is not necessarily published information available in the public domain that supports registration of each product, and given the limited information about commercial trials with $1-\mathrm{MCP}$, it is necessary to speculate about the potential for 1-MCP based on the published literature. In reviewing this literature, it is important to recognize that scientific publications tend by their nature to accentuate negative responses without necessarily providing a commercial context for the results. Storage experiments, for example, often involve "storing to exhaustion," that is, storing produce for lengths beyond commercial viability to accentuate differences among treatments. Careless interpretation of this literature could in some cases provide misleading inferences about the commercialization of 1-MCP for some crops. 


\section{THE EFFECTS OF 1-METHYLCYCLOPROPENE ON SELECTED CROPS}

Most research has been carried out on apple [Malus sylvestris (L.) Mill. var. domestica (Borkh.) Masf.], avocado (Persea americana Mill.), banana (Musa sp., AAA group, Cavendish subgroup), plum (Prunus domestica L. and Prunus salicina L.), peach and nectarine (Prunus persica L.), pear (Pyrus communis L.), and tomato (Solanum esculentum Mill) (Watkins, 2006; Watkins and Miller, 2006). Of these fruit, however, apple appears the most straightforward for 1-MCP-based technology, partly because of its unique ripening characteristics. Fruit can be divided into two ripening types based on texture changes after harvest (Bourne, 1979). The first group represented by apple and nashi have a crisp texture after ripening, and in general, maintenance of texture similar to that at harvest is desirable in the marketplace. The second type of fruit represented by banana, peach, pear, and tomato develop a melting flesh. Softening is associated with changes of color and flavor factors such as soluble solids concentration, acidity, and aroma that are characteristic of the product. Use of 1-MCP can be more difficult for these fruit because it is necessary to delay, but not inhibit, ripening and hence requires precise modulation of 1-MCP concentration and exposure time.

The effects of 1-MCP on apple, avocado, banana, plum, peach and nectarine, pear, and tomato have been reviewed by Watkins (2006) and therefore only a summary of effects described in that review is provided here. In addition, the effects of 1-MCP on apricot (Prunus armeniaca L.), kiwifruit [Actinidia deliciosa (A. Chev.) C.F. Liang at A.R. Ferguson var deliciosa], melon (Cucumis melo L., reticulatus), mango (Mangifera indica L.), and persimmon (Diospyros kaki L.), for which significant information is available, and on broccoli (Brassica oleracea L.), the only nonfruit vegetable, are reviewed. $1-\mathrm{MCP}$ is registered for other fruit (Table 1), but an insufficient body of work exists to speculate on the potential of the technology.

Apple. 1-MCP-based technology has been incorporated rapidly by apple industries around the world. Although the percentages of the apple crop treated with 1-MCP within various growing regions are not publicly available, anecdotal reports suggest that the majority of some cultivars stored in CA are treated with 1-MCP in New York and Washington. The reason for the popularity of $1-\mathrm{MCP}$ for the apple is that treated fruit maintain firmness throughout the whole marketing chain. Firmness is a major factor in consumer preferences (Harker et al., 2002; Kupferman, 2005). Although CA storage maintains firmness of fruit during storage, softening takes place during subsequent transport and marketing. In contrast, 1-MCPtreated fruit of some cultivars soften little during shelf-life periods (Watkins et al., 2000).
The rapid incorporation of 1-MCP-based technology into apple industries has made it an excellent "test" crop for identification of strengths and weaknesses of the technology and has implications for other fruit types. The "apple" is fruit with a wide range of cultivars, each with differing ripening rates, harvest criteria, postharvest handling procedures, and storage periods in air and CA (Watkins, 2003), and it is therefore not surprising that these factors affect responses to 1-MCP (Table 2). For example, some cultivars respond poorly, either showing little response or losing effects rapidly during storage, compared with others (Fig. 1). These responses may be a combination of the effects of the internal ethylene concentration (IEC) at harvest and the physiology of the cultivars in their abilities to develop new ethylene receptor sites. The IEC at harvest for the cultivars in Figure 1 were 9.8, 0.9, 67.0, 1.8 and $78.6 \mu \mathrm{L} \cdot \mathrm{L}^{-1}$ for 'Empire', 'Cortland', 'McIntosh', 'Idared', and 'Northern Spy', respectively.

Also, within a cultivar, variations in response exist, typically later harvested fruit being less responsive that earlier harvested fruit (Mir et al., 2001; Watkins and Nock,
2005; Watkins et al., 2000), and these can affect commercial success. The responsiveness of a given cultivar to 1-MCP also can vary among growing regions (unpublished data), perhaps also related to ethylene production by fruit at the time of harvest and subsequent potential for production during storage.

Another feature of the apple is that fruit are typically accumulated for several days to fill a room before application of CA storage. Delays between harvest and treatment of fruit with 1-MCP affect responses to 1-MCP (Watkins and Nock, 2005), and longer delay periods before 1-MCP treatment are associated with increasing ethylene concentrations in the fruit (Fig. 2) and reduced effectiveness of treatment (Fig. 3). Differences among cultivars are reflected in commercial recommendations for the time between harvest and 1-MCP treatment (SmartFresh, 2006).

Formal consumer studies on the effects of 1-MCP are limited, but treated 'Anna' apples had less fruity, ripe, and overall aromas, but were firmer, crisper, juicier, and less mealy, and preferred over untreated fruit by sensory panelists (Lurie et al., 2002; Pre-Aymard et al., 2005). Some aroma volatiles can be associated with overripening and therefore inhibition of

Table 1. Horticultural crops registered for commercial 1-methylcyclopropene around the world as of 2006.

\begin{tabular}{ll}
\hline Country & \\
\hline Argentina & Apple, pear, plum, tomato \\
Australia & Apple, avocado, melon, tomato, and pear \\
Austria & Apple \\
Belgium & Apple \\
Brazil & Apple, avocado, bananas, guava, mango, melon, papaya, tomato \\
Canada & Apple, pear, plum, tomato \\
Chile & Apple, avocado, banana, cherimoya, guava, mango, pear, plum, tomato \\
China & Apple, kiwifruit, persimmon \\
Costa Rica, Guatemala, & \\
and Honduras & Avocado, banana, mango, melon, papaya, pineapple, plantain, tomato \\
Israel & Apple, avocado, persimmon \\
France & Apple, plum \\
Germany & Apple \\
Israel & Apple, avocado, persimmon \\
Korea & Apple \\
Mexico & Apple, avocado, cucumbers, dates, kiwifruit, mango, melon, nectarine, \\
& papaya, peach, pear, pepper, persimmon, plum, squash, tomato \\
New Zealand & Apple, avocado, kiwifruit, melon, persimmon, tomato \\
Nicaragua & Avocado, banana, mango, melon, papaya, pineapple, plantain, tomato \\
South Africa & Apple, avocado, kiwifruit, plum, tomato \\
Switzerland & Apple \\
The Netherlands & Apple \\
UK & Apple \\
USA & Apple, apricot, avocado, banana, broccoli, kiwifruit, mango, melon, \\
& nectarine, papaya, peach, pear, persimmon, plum, tomato \\
\hline
\end{tabular}

Table 2. Summary of factors that have been shown to affect responses of apple fruit to 1-methylcyclopropene with selected references.

\begin{tabular}{|c|c|}
\hline Factor & Reference \\
\hline Cultivar & $\begin{array}{l}\text { Bai et al., 2005; Dauny and Joyce, 2002; Fan et al., 1999; } \\
\text { Rupasinghe et al., 2000; Watkins et al., } 2000\end{array}$ \\
\hline Maturity & Mir et al., 2001; Watkins and Nock, 2005; Watkins et al., 2000 \\
\hline $\begin{array}{l}\text { Storage type } \\
\text { (air compared with CA) }\end{array}$ & Watkins and Nock, 2005; Watkins et al., 2000 \\
\hline $\begin{array}{l}\text { Storage temperature } \\
\text { Time between harvest and }\end{array}$ & Fan and Mattheis, 2001; Mir et al., 2001; Toivonen and Lu, 2005 \\
\hline $\begin{array}{l}\text { Time between harvest and } \\
\text { 1-methylcyclopropene treatment }\end{array}$ & Watkins and Nock, 2005 \\
\hline $\begin{array}{l}\text { Repeated 1-methylcyclopropene } \\
\text { application } \\
\text { DPA metabolism and degradation } \\
\text { Bin materials }\end{array}$ & $\begin{array}{l}\text { Jayanty et al., } 2004 \\
\text { Arquiza et al., 2005; Rudell et al., } 2006 \\
\text { Vallejo and Beaudry, } 2006\end{array}$ \\
\hline
\end{tabular}

DPA, diphenylamine. 

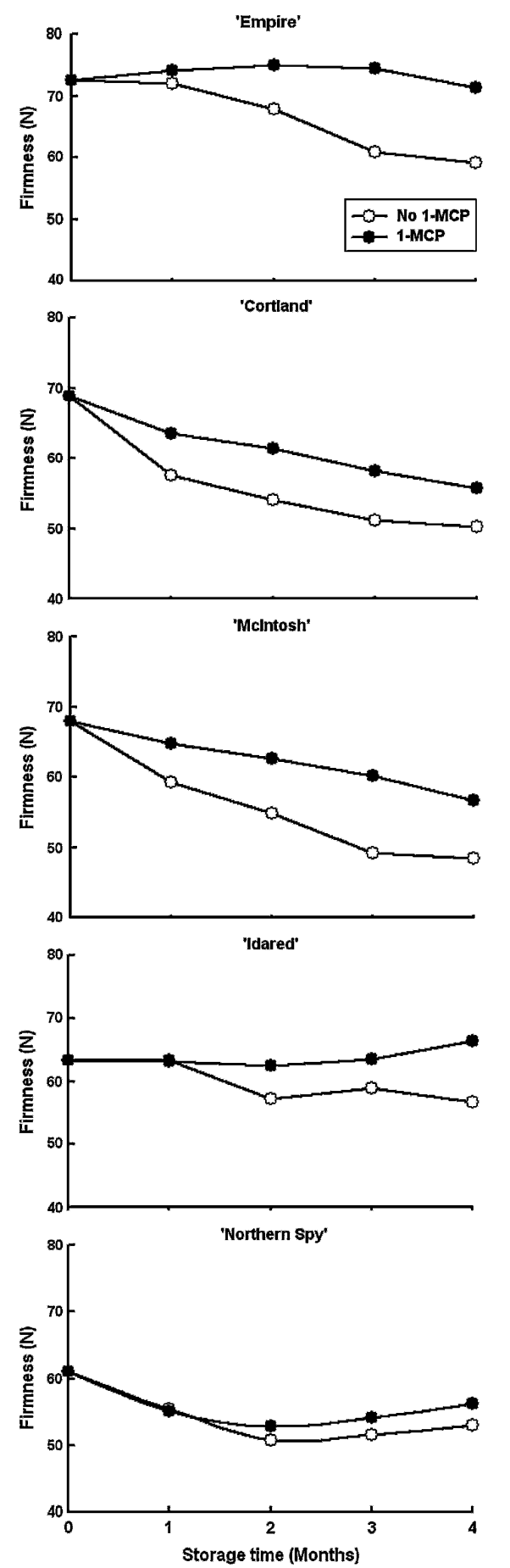

Fig. 1. Firmness $(\mathrm{N})$ of 'Empire', 'McIntosh', 'Cortland', 'Idared' and 'Northern Spy' apple fruit untreated or treated with $1 \mu \mathrm{L} \cdot \mathrm{L}^{-1} 1$ methylcyclopropene on the day of harvest and stored at $1{ }^{\circ} \mathrm{C}$ for 4 months. Three replicate samples of 10 fruit were assessed at harvest and at monthly intervals after removal of fruit from storage plus $1 \mathrm{~d}$ at $20{ }^{\circ} \mathrm{C}$ (Watkins and Nock, unpublished data). The least significant difference at $P \leq 0.05$ for treatment $\times$ storage time is $4.0,3.1,3.9$, and $3.5 \mathrm{~N}$ for 'Empire', McIntosh', 'Cortland', and 'Idared', respectively. No significant effects were detected for 'Northern Spy'.

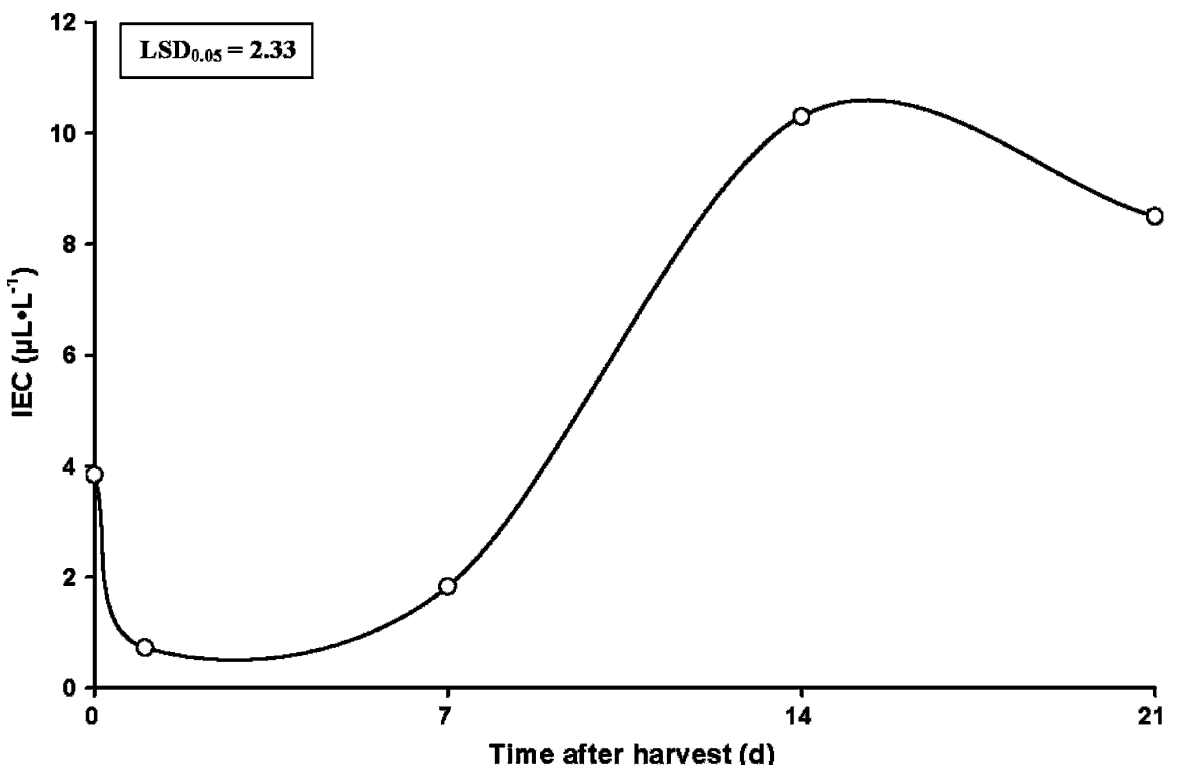

Fig. 2. Internal ethylene concentration (IEC; $\mu \mathrm{L} \cdot \mathrm{L}^{-1}$ ) of 'Jonagold' apple fruit at harvest and during cold storage at $0.5^{\circ} \mathrm{C}$. Fruit were treated with $1 \mu \mathrm{L} \cdot \mathrm{L}^{-1} 1$-methylcyclopropene on the day of harvest (warm) and after 1, 7, 14, and $21 \mathrm{~d}$. Each value represents the mean of data for three replicates of 10 fruit (Watkins and Nock, unpublished data).

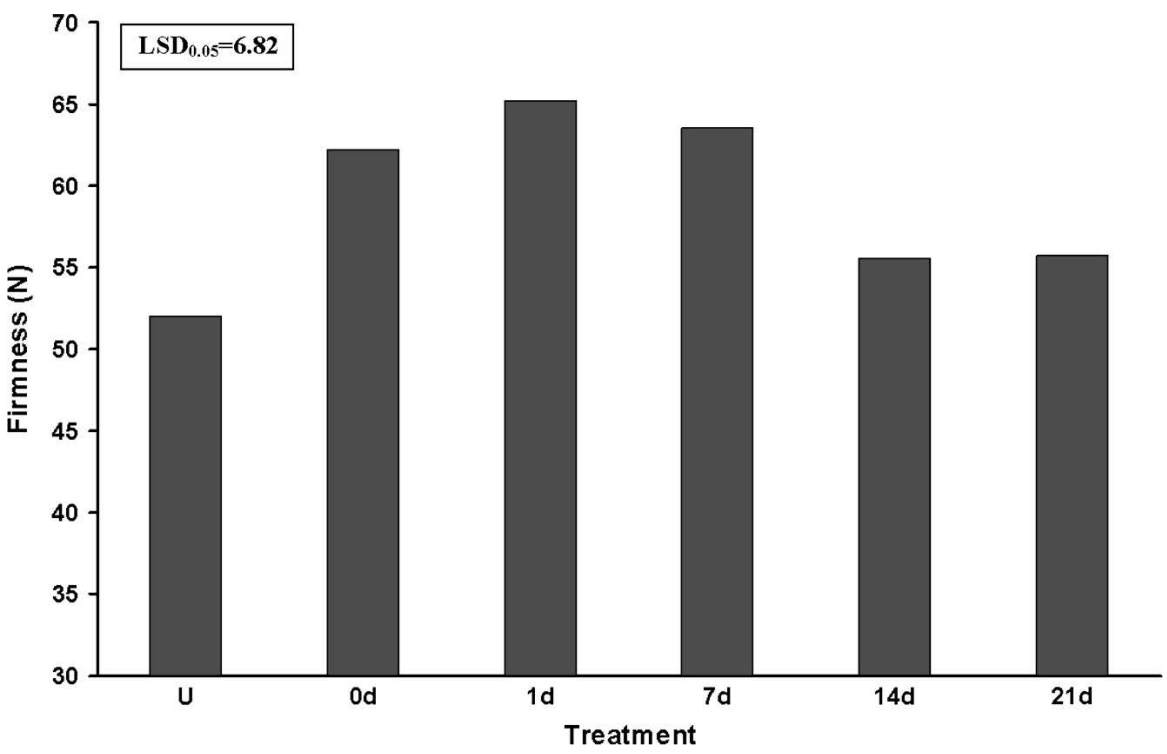

Fig. 3. Firmness $(\mathrm{N})$ of 'Jonagold' apple fruit after storage in CA ( $2 \%$ carbon dioxide and $2 \%$ oxygen $)$ at $0.5{ }^{\circ} \mathrm{C}$ for 5 months plus $1 \mathrm{~d}$ at $20^{\circ} \mathrm{C}$. Fruit were either untreated $(\mathrm{U})$ or treated with $1 \mu \mathrm{L} \cdot \mathrm{L}^{-1}$ 1-methylcyclopropene on the day of harvest (warm) and after 1, 7, 14, and $21 \mathrm{~d}$. Each value represents the mean of data for three replicates of 10 fruit (Watkins and Nock, unpublished data).

these by 1-MCP can be desirable. Nevertheless, inhibition of desirable volatiles is a factor that must be taken into consideration for some cultivars. For example, 'McIntosh' apples have a maximum firmness preference with fruit being firmer or softer than $58 \mathrm{~N}$ being less preferred (Liu and King, 1978), and also is an apple that has high consumer requirements for aroma volatiles as it softens. Therefore, certain cultivars may require partial recovery from 1-MCP inhibition that allows some softening and volatile development to meet expectations of the marketplace.

Apples are susceptible to a range of physiological disorders. Interestingly, 1-MCP inhibits or delays the development of some disorders such as senescent breakdown and superficial scald while increasing sensitivity to others such as external carbon dioxide injury. The effects of 1-MCP on physiological disorders of apple and other fruit may be categorized according to the role of ethylene in causing or preventing these disorders (Table 3). The effects of 1-MCP on some disorders are not yet understood. For example, the incidence of a form of flesh-browning of 'Empire' apples that has been traditionally associated with low storage temperatures was higher in 1-MCP-treated fruit stored at $3{ }^{\circ} \mathrm{C}$ compared with fruit stored at $0.5{ }^{\circ} \mathrm{C}$ (Table 4). Further research is required to understand the complex interactions between ethylene and storage environments for this and other disorders. 
Table 3. Examples of the effects of 1-methylcyclopropene on physiological disorders categorized by those that are senescence, storage temperature, or storage atmosphere-related.

\begin{tabular}{|c|c|c|}
\hline Disorder category & Example & Reference \\
\hline \multirow[t]{3}{*}{$\begin{array}{l}\text { Senescence-related prevented by inhibition } \\
\text { of ethylene production }\end{array}$} & Senescent breakdown of apple & $\begin{array}{l}\text { DeLong et al., 2004; Moran and McManus, 2005; } \\
\text { Watkins et al., } 2000\end{array}$ \\
\hline & $\begin{array}{l}\text { Senescent scald and breakdown } \\
\text { (senescent, watery, core) of pear }\end{array}$ & $\begin{array}{l}\text { Argenta et al., 2003; Calvo and Sozzi, 2004; } \\
\text { Ekman et al., 2004; Kubo et al., } 2003\end{array}$ \\
\hline & Poststorage internal browning of apricot & Dong et al., 2002 \\
\hline \multirow[t]{5}{*}{$\begin{array}{l}\text { Chilling-related that are prevented by inhibition of } \\
\text { ethylene production }\end{array}$} & $\begin{array}{l}\text { Superficial scald, brown core (coreflush), } \\
\text { and soft scald of apple and pear }\end{array}$ & $\begin{array}{l}\text { Arquiza et al., 2005; Fan and Mattheis, 1999; } \\
\text { Pechous et al., 2005; Watkins et al., } 2000\end{array}$ \\
\hline & Internal flesh browning of avocado & $\begin{array}{l}\text { Hershkovitz et al., 2005; Pesis et al., 2002; } \\
\text { Woolf et al., } 2005\end{array}$ \\
\hline & Internal flesh browning of pineapple & Selvarajah et al., 2001 \\
\hline & Tissue gelation of persimmon & Salvador et al., 2004 \\
\hline & CI of melon & Gal et al., 2006 \\
\hline \multirow[t]{4}{*}{$\begin{array}{l}\text { Chilling-related that are increased by inhibition of } \\
\text { ethylene production }\end{array}$} & $\begin{array}{l}\text { Wooliness and internal breakdown of } \\
\text { peach and nectarine }\end{array}$ & $\begin{array}{l}\text { Dong et al., 2001; Fan et al., 2002; } \\
\quad \text { Girardi et al., } 2005\end{array}$ \\
\hline & Internal reddening of plums & Dong et al., 2002 \\
\hline & $\mathrm{CI}$ of citrus & Dou et al., 2005; Porat et al., 1999 \\
\hline & CI of bananas & Jiang et al., 2004 \\
\hline \multirow[t]{3}{*}{$\begin{array}{l}\text { Ethylene-induced prevented by inhibition of } \\
\text { ethylene production }\end{array}$} & Browning of lettuce & $\begin{array}{l}\text { Fan and Mattheis, 2000a; Saltveit, 2004; } \\
\text { Tay and Perera, 2004; Wills et al., } 2002\end{array}$ \\
\hline & Isocoumarin accumulation in carrot & Fan and Mattheis, 2000a; Fan et al., 2000 \\
\hline & Water soaking of watermelon & Mao et al., 2004a, 2004b \\
\hline CA-related increased by inhibition of ethylene production & External $\mathrm{CO}_{2}$ injury of apple & DeEll et al., 2003; Zanella, 2003 \\
\hline
\end{tabular}

$\mathrm{CI}=$ chilling injury.

Table 4. Flesh browning (\%) of 'Empire' apples harvested from three orchards in the Hudson Valley and Western New York untreated or treated with $1 \mu \mathrm{L} \cdot \mathrm{L}^{-1} 1$-methylcyclopropene for $24 \mathrm{~h}{ }^{2}$

\begin{tabular}{lcccc}
\hline & \multicolumn{3}{c}{ Flesh browning $(\%)$} \\
\cline { 2 - 5 } & \multicolumn{2}{c}{ Hudson Valley } & \multicolumn{2}{c}{ Western New York } \\
\cline { 2 - 5 } Storage temp $\left({ }^{\circ} \mathrm{C}\right)$ & $6 \mathrm{~b}$ & $2 \mathrm{~b}$ & $1-\mathrm{MCP}$ & $+1-\mathrm{MCP}$ \\
\hline 0.5 & $0 \mathrm{c}$ & $54 \mathrm{a}$ & $21 \mathrm{~b}$ & $14 \mathrm{c}$ \\
3.0 & $-1-\mathrm{MCP}$ & $+1-\mathrm{MCP}$ & & $41 \mathrm{a}$ \\
\hline
\end{tabular}

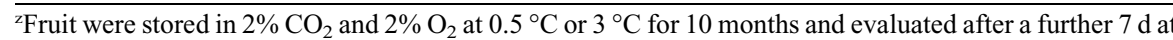
$20{ }^{\circ} \mathrm{C}$ (Watkins and Nock, unpublished data). Different letters indicate significant differences $(P \leq 0.05)$ between means within each region.

It is likely that apple industries will continue to incorporate 1-MCP technology into their operations, but it is also likely that new issues will continue to arise as different cultivars grown under different climates are treated. It is useful to compare CA storage technology with that based on 1-MCP. Recommendations for CA regimes vary greatly according to cultivar and, within a cultivar, can also vary according to growing region. The physiological underpinnings of these differences are likely to impact strategies for 1-MCP use.

Apricot. Softening of apricots can be inhibited by 1-MCP treatment, even when fruit are ripe at the time of treatment (Botondi et al., 2003; Fan et al., 2000). Depending on cultivar and ripening stage when treated, the effects of 1-MCP on softening can be small but significant. 1-MCP can reduce ripening induced by impact injury (de Martino et al., 2006). Volatile production of treated fruit is inhibited by 1-MCP treatment (Fan et al., 2000), but not easily detected by sensory evaluation (Botondi et al., 2003). Nevertheless, attention to the cultivar harvest date in relation to effects on volatiles may be important (Botondi et al., 2003).

Quality of 1-MCP-treated fruit in cold storage can be poorer than that of untreated fruit (Dong et al., 2002). Internal browning of fruit is higher in cold-stored apricots, but incidence of the disorder decreases if fruit are treated after removal from cold storage (Dong et al., 2002).

Avocado. Responses of avocado fruit to $1-\mathrm{MCP}$ are usually "concentration $\times$ exposure time"-dependent (Feng et al., 2000; Jeong et al., 2002), and treated fruit are firmer, slower to soften, and slower to change skin color (Adkins et al., 2005; Feng et al., 2000, 2004; Hershkovitz et al., 2005; Woolf et al., 2005). Successful use of 1-MCP requires delayed but not inhibited ripening.

1-MCP shows promise as a tool to reduce physiological disorders such as internal but not external chilling injury (CI) (Pesis et al., 2002; Woolf et al., 2005). Also, excessive delays of ripening can increase decay development (Adkins et al., 2005; Hofman et al., 2001; Woolf et al., 2005). Thus, extending storage periods is not necessarily beneficial per se; fruit resistance to infection and greater inoculum control in the field before harvest may become more important for successful storage (Adkins et al., 2005).

Banana. 1-MCP increases the green life of banana, responses usually being "concentration $\times$ exposure time" -dependent (Bagnato et al., 2003; Harris et al., 2000; Jiang et al., 1999).

Successful use of 1-MCP requires delayed, and then uniform, ripening, but strategies to achieve this may be difficult. A wide range of finger maturity in banana bunches can result in uneven color development (Harris et al., 2000), and 1-MCP can cause partial disruption of ripening events (Golding et al., 1998; Pelayo et al., 2003). An interesting feature about the application of 1-MCP to banana is that this crop represents one for which harvest, handling, and transport is tightly managed by a limited number of companies. It is possible that successful commercialization of 1-MCP may occur with little publicly available information.

Broccoli. The only nonfruit vegetable that has been registered for 1-MCP use is broccoli (Table 1). 1-MCP delays yellowing and development of decay in a "concentration $\times$ exposure time"-dependent manner (Fan and Mattheis, 2000b; Gong and Mattheis, 2003; $\mathrm{Ku}$ and Wills, 1999). However, as is the situation with many studies with leafy vegetables, nonclimacteric fruit, and ornamental plants, effects of 1-MCP cannot be detected unless broccoli are treated with exogenous ethylene. Commercial utilization of 1-MCP for broccoli and other similar crops may be effective only where abusive conditions occur such as higher temperatures and the presence of exogenous ethylene as would be found during handling, transportation, and marketing.

Kiwifruit. Kiwifruit are extremely sensitive to exogenous ethylene, and exposure to the gas can result in premature ripening (MacRae et al., 1989). The effects of 1-MCP on ripening of kiwifruit are variable; 1-MCP delays softening when fruit are treated at harvest (Boquete et al., 2004; Kim et al., 2001; Minniti et al., 2005), but the effects are lost during cold storage, even at high (10 and $100 \mu \mathrm{L} \cdot \mathrm{L}^{-1}$ ) 1-MCP concentrations (Kim et al., 2001). Colelli and Amodio (2003) detected no effect of 1-MCP on fruit treated after cold storage. Advantages of 1-MCP technology may lie in providing flexibility in grading, packaging, and transportation 
operations (Boquete et al., 2004), but overall, benefits of 1-MCP appear limited for kiwifruit.

Mango. Days to ripen, as indicated by softening and loss of chlorophyll, can be increased, and increases in soluble solids concentrations and aroma volatiles can be delayed by 1-MCP treatment (Alves et al., 2004; Hofman et al., 2001; Jiang and Joyce, 2000; Lalel et al., 2003). In these studies, the effects of 1-MCP were "concentration $\times$ exposure time"-dependent. However, in Brazilian studies, low (30 and $120 \mathrm{~nL} \cdot \mathrm{L}^{-1}$ ) 1-MCP concentrations delayed ripening (Alves et al., 2004, and ripening was accelerated by $500 \mathrm{~nL} \cdot \mathrm{L}^{-1} 1-\mathrm{MCP}$ (Cocozza et al., 2004). In contrast, the 1-MCP concentrations necessary to obtain effects in other studies are very high ( 25 to $100 \mu \mathrm{L} \cdot \mathrm{L}^{-1}$; Hofman et al., 2001; Jiang and Joyce, 2000; Lalel et al., 2003), perhaps because of the skin diffusion characteristics of the fruit. Although 1-MCP treatment in combination with sealed polyethylene bags could provide a feasible technology where ambient temperature storage is required (Jiang and Joyce, 2000), such high 1-MCP concentrations could make 1-MCP uneconomic. Vacuum infiltration can reduce the effective 1-MCP concentrations to as low as $1 \mu \mathrm{L} \cdot \mathrm{L}^{-1}$, whereas 5 $\mu \mathrm{L} \cdot \mathrm{L}^{-1} 1-\mathrm{MCP}$ increased the storage period from $8 \mathrm{~d}$ to $12 \mathrm{~d}$ (Wang et al., 2006). Whether the benefits in storage time would justify the expense of vacuum technology is uncertain. 1-MCP also doubled the decay incidence (stem rots) compared with untreated fruit (Hofman et al., 2001).

Melon. The rate of softening of melons is decreased by 1-MCP (Alves et al., 2005; de Lima et al., 2004; Ergun et al., 2005; Gal et al., 2006). Ripening stage at time of treatment can be important; inhibition of softening by 1-MCP is greater in green than yellow fruit but may result in unacceptable maintenance of firmness (Gal et al., 2006). High 1-MCP concentrations cause a dissociation of ripening recovery between mesocarp and epidermal tissues, especially in less mature fruit (Ergun et al., 2005). Softening of yellow melons was inhibited in the study of Ergun et al. (2005), but not that of Gal et al. (2006), perhaps because of higher 1-MCP concentrations used in the former study. Treatment of fruit at the green-yellow stage with 300 $\mathrm{nL} \cdot \mathrm{L}^{-1} 1-\mathrm{MCP}$ resulted in desirable delays in yellowing and softening (Gal et al., 2006). $1-\mathrm{MCP}$ can double the storage life of melons (Alves et al., 2005). Internal quality of treated fruit is superior to untreated fruit (de Lima et al., 2004) with lower sensitivity of fruit to CI and decay (Gal et al., 2006). Melon appears to be a suitable candidate for 1-MCP technology given appropriate attention to cultivar and ripening stage in relation to 1-MCP concentration applied.

Peach and nectarine. Responses of peach and nectarine to 1-MCP are "concentration $x$ exposure time"-dependent, but effective concentrations can vary widely $\left(0.4\right.$ to $\left.5 \mu \mathrm{L} \cdot \mathrm{L}^{-1}\right)$ (Liguori et al., 2004; Liu et al., 2005). Softening of peaches can be delayed, but effects are typically small and transitory (Bregoli et al., 2005; Dal Cin et al., 2006; Dong et al., 2001; Fan et al., 2002; Liu et al., 2005). Softening of fruit by $1-$ MCP can be more consistently controlled with repeated 1-MCP applications (Liu et al., 2005), but are not commercially practical. Interestingly, despite the limited effects at room temperature, 1-MCP can increase development of chilling-related injuries at low temperature (Dong et al., 2001; Fan et al., 2002). These results suggest that normal ethylene-mediated ripening is necessary to prevent such injuries (Table 2) and suggest that use of 1-MCP to extend low-temperature storage periods may be limited.

Pear. Responses of pears to 1-MCP are "concentration $\times$ exposure time"-dependent (Argenta et al., 2003; Ekman et al., 2004). However, the 1-MCP concentrations that delay but not inhibit fruit ripening are variable and are affected by cultivar, variations of fruit maturity at harvest, storage conditions, and storage period (Argenta et al., 2003; Bai et al., 2006; Calvo and Sozzi, 2004; Ekman et al., 2004; Kubo et al., 2003; Moya-Leon et al., 2006; Trinchero et al., 2004). These factors make it difficult to develop correct 1-MCP concentrations for commercial application of 1-MCP, and failure of fruit to ripen is a common observation in 1-MCP studies. In addition, lack of uniformity of response to 1-MCP (Trinchero et al., 2004) and dissociation of ripening processes such as skin color and softening (Ekman et al., 2004) could be problematic at the retail level. One approach to overcoming undesirable sensitivity of pears to 1-MCP is a preconditioning treatment that involves selection of 1-MCP concentration, storage time and atmosphere, and temperature (Bai et al., 2006).

An important benefit of $1-\mathrm{MCP}$ is that it reduces susceptibility of fruit to vibration and impact bruising, and to skin browning, suggesting that its use could lead to benefits during postharvest handling operations (Calvo and Sozzi, 2004; Ekman et al., 2004). Successful commercial application of 1-MCP will be reliant on choice of appropriate cultivars and postharvest handling strategies.

Persimmon. 1-MCP delays softening of persimmon with or without astringency removal procedures (Harima et al., 2003; Luo, 2007; Nakano et al., 2002; Ortiz et al., 2005; Salvador et al., 2004). 1-MCP concentrations required to obtain effects vary greatly, however, from $0.1 \mu \mathrm{L} \cdot \mathrm{L}^{-1}$ (Harima et al., 2003) to $3 \mu \mathrm{L} \cdot \mathrm{L}^{-1}$ (Luo, 2007), differences perhaps related to cultivar. Delays between harvest and treatment reduce beneficial effects of 1-MCP, and Harima et al. (2003) recommend treatment within $12 \mathrm{~h}$ of harvest. Interestingly, the availability of gas treatment facilities for removal of astringency provides facilities for 1-MCP treatment at little additional cost. 1-MCP also reduces calyx abscission and softening associated with CI development, suggesting that 1-MCP-treated fruit could be stored at lower temperatures to increase storage potential of the fruit (Salvador et al., 2004).

Plum. Softening and skin color changes of plums are delayed by 1-MCP (Dong et al., 2002; Martinez-Romero et al., 2003; Valero et al., 2003, 2004). Plums are "concentration $\times$ exposure time" -dependent for normal ethylene-producing cultivars, but not for suppressed climacteric cultivars (Abdi et al., 1998; Martinez-Romero et al., 2003). Effects of 1-MCP are also affected by fruit maturity and can be effective at later maturity stages when better-quality characteristics have developed (Salvador et al., 2003; Valero et al., 2003). Although results suggest that plums may be a suitable fruit for 1-MCPbased technology, the most important issue may be the extent to which "1-MCP concentration $\times$ exposure time" relationships can be calibrated for different cultivars. Interestingly, the plum is one of few fruit other than apple for which postharvest handling issues have been investigated; Valero et al. (2004) found that packaged plum fruit responded better to 1-MCP than bulk-packed fruit.

Tomato. 1-MCP can delay ripening of tomato fruit, but effects are related to cultivar (Krammes et al., 2003), "1-MCP concentration $\times$ exposure time," and ripening stage (Hurr et al., 2005; Mir et al., 2004; Mostofi et al., 2003; Opiyo and Ying, 2005; Sisler et al., 1996; Wills and $\mathrm{Ku}, 2006$ ). Fruit treated at the mature green stage do not ripen as uniformly as fruit that are treated at more mature ripening stages (Hurr et al., 2005; Mostofi et al., 2003). Benefits of 1-MCP treatment, and thus potentially better fruit quality for the consumer, can be detected even for fruit treated when ripe (Guillen et al., 2006; Hurr et al., 2005) Inconsistent ripening within the fruit (locular compared with pericarp tissues) may affect acceptability of fresh-cut slices from 1-MCP-treated tomatoes (Mir et al., 2004).

\section{THE EFFECTS OF 1-METHYLCYCLOPROPENE ON PHYSIOLOGICAL AND PATHOLOGICAL DISORDERS}

In addition to the effects of 1-MCP on ripening and senescence of fruit and vegetables, 1-MCP can greatly influence susceptibility of these products to physiological and pathological disorders. These effects must be taken into account in commercial application of 1-MCP-based technology.

The effects of 1-MCP in physiological disorders have been reviewed in greater detail elsewhere (Watkins, 2007). Physiological disorders can be separated into several categories that represent the diverse influence of ethylene on their development (Table 3). Not surprisingly, those that are senescence or ethylene-related are inhibited by 1-MCP, but the effects of 1-MCP on CIs are interesting. One group of CIs are associated with ethylene action and therefore are inhibited by 1-MCP, whereas the other group are associated with lesions of normal ripening and 
Table 5. Examples of pathological disorders for which the incidences are increased, decreased, or unaffected by application of 1-methylcyclopropene to fruit and vegetables.

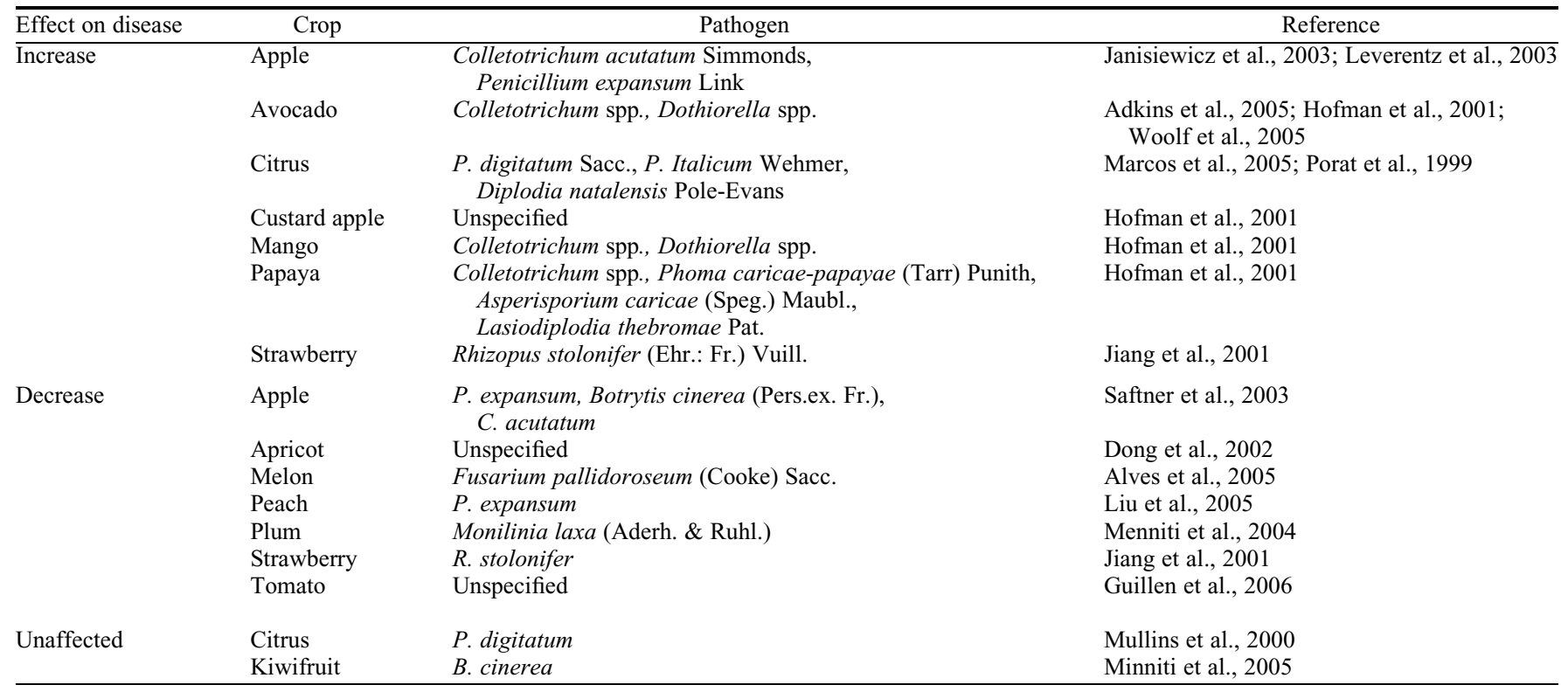

therefore are increased by inhibited ripening that occurs when fruit are treated with 1-MCP. However, CI in mandarin can be inhibited by increased ethylene production induced by 1-MCP treatment (Salvador et al., 2006) indicating how complex these interactions can be. Another group appears to be associated with the interaction between effects of 1-MCP and storage atmosphere.

Pathological disorders can be separated into those that are increased, decreased, or unaffected by 1-MCP application (Table 5). Many of these studies involve inoculation of the product with the pathogen and results are not always consistent even within a product. In strawberry, for example, disease incidence was lower at low 1-MCP concentrations and increased at higher 1-MCP concentrations (Jiang et al., 2001; Ku et al., 1999). Interactions between products and pathogens can be complex and are affected by the environment. 1-MCP may affect the product susceptibility to the disease complex simply by influencing factors such as skin integrity and firmness. Interestingly, however, ethylene can be an important component of product resistance because it regulates defense genes (Marcos et al., 2005), and these defenses may be compromised by 1-MCP (Jiang et al., 2001).

The effects of 1-MCP on disease resistance may be more significant as 1-MCP is commercialized. The commercial environment presents a more varied inoculum source than that under laboratory conditions, and disease susceptibility may be greater. Increased disease incidence in avocado, for example, was associated with increased storage periods and suggests that preharvest disease control may become more important for 1-MCP-treated fruit (Adkins et al., 2005).

\section{SUMMARY}

1-MCP provides an exciting era for postharvest scientists as they work with horticul- tural industries to explore the commercial potential of this new technology. Availability of information about commercial trials is still limited, and understanding the full potential of 1-MCP remains speculative. Challenges exist in identifying the 1-MCP concentrations that will delay, but not inhibit, ripening of many fruits. In addition, to the success story of the apple, the fruit that appear to have the greatest potential for application of 1-MCP technology, are the avocado, melon, persimmon, plum, and tomato, although niche opportunities for others may exist.

Handling practices in commercial practice will need to take into account cultivar, maturity and ripening stage, time between harvest and treatment, treatment temperature, and desired effects on quality that may vary through the distribution pathway. In addition, little information about preharvest effects on $1-\mathrm{MCP}$ responses is available. Each of these factors may affect the 1-MCP concentration $\times$ exposure time suitable for each product. The extent to which this is realistic in the relatively uncontrolled world of fruit and vegetable production is uncertain.

Finally, commercialization of 1-MCP will also be dependent on the cost of the technology relative to the benefits on the product. Cost of the technology involves not only that associated directly with 1-MCP application, but how successfully the technology can be incorporated into handling, storage, and transportation systems. Benefits include perceived effects on quality in relation to competition in the marketplace, the scale of the industry involved, and possible access to markets that are not available using current technologies.

\section{Literature Cited}

Abdi, N., W.B. McGlasson, P. Holford, M. Williams, and Y. Mizrahi. 1998. Responses of climacteric and suppressed-climacteric plums to treatment with propylene and 1methylcyclopropene. Postharvest Biol. Tech. 14:29-39.

Adkins, M.E., P.J. Hofman, B.A. Stubbings, and A.J. Macnish. 2005. Manipulating avocado fruit ripening with 1-methylcyclopropene. Postharvest Biol. Tech. 35:33-42.

Alves, R.E., H.A.C. Filgueiras, A.S. Almeida, F.L.C. Machado, M.S.R. Bastos, M.A.C. Lima, D. Terao, E.O. Silva, E.C. Santos, M.E.C. Pereira, and M.R.A. Miranda. 2005. Postharvest use of 1-MCP to extend storage life of melon in Brazil - current research status. Acta Hort. 682:2233-2237.

Alves, R.E., H.A.C. Filgueiras, M.E.C. Pereira, F.M. Cocozza, and J.T. Jorge. 2004. Postharvest ripening of 'Tommy Atkins' mangoes on two maturation stages treated with 1-MCP. Acta Hort. 645:627-632.

Argenta, L.C., X.T. Fan, and J.P. Mattheis. 2003. Influence of 1-methylcyclopropene on ripening, storage life, and volatile production by d'Anjou cv. pear fruit. J. Agr. Food Chem. 51:3858-3864.

Arquiza, J.M.R.A., A.G. Hay, J.F. Nock, and C.B. Watkins. 2005. 1-Methylcyclopropene (1-MCP) interactions with diphenylamine degradation, superficial scald metabolism, and polyphenol oxidase and peroxidase activities in apple fruit. J. Agr. Food Chem. 53:7565-7570.

Bagnato, N., R. Barrett, M. Sedgley, and A. Klieber. 2003. The effects on the quality of Cavendish bananas, which have been treated with ethylene, of exposure to 1-methylcyclopropene. Intl. J. Food Sci. Tech. 38:745-750.

Bai, J.H., E.A. Baldwin, K.L. Goodner, J.P. Mattheis, and J.K. Brecht. 2005. Response of four apple cultivars to 1-methylcyclopropene treatment and controlled atmosphere storage. HortScience 40:1534-1538.

Bai, J., J.P. Mattheis, and N. Reed. 2006. Reinitiating softening ability of 1-methylcyclopropene-treated 'Bartlett' and ' $\mathrm{d}$ 'Anjou' pears after regular air or controlled atmosphere storage. J. Hortic. Sci. Biotechnol. 81:959-964.

Blankenship, S.M. and J.M. Dole. 2003. 1-Methylcyclopropene: A review. Postharvest Biol. Tech. 28:1-25. 
Boquete, E.J., G.D. Trinchero, A.A. Fraschina, F. Vilella, and G.O. Sozzi. 2004. Ripening of 'Hayward' kiwifruit treated with 1-methylcyclopropene after cold storage. Postharvest Biol. Tech. 32:57-65.

Botondi, R., D. DeSantis, A. Bellincontro, K. Vizovitis, and F. Mencarelli. 2003. Influence of ethylene inhibition by 1-methylcyclopropene on apricot quality, volatile production, and glycosidase activity on low- and higharoma varieties of apricots. J. Agr. Food Chem. 51:1189-1200.

Bourne, M.C. 1979. Texture of temperate fruit. J. Texture Stud. 10:25-44.

Bregoli, A.M., V. Ziosi, S. Biondi, A. Rasori, M. Ciccioni, G. Costa, and P. Torrigiani. 2005. Postharvest 1-methylcyclopropene application in ripening control of 'Stark Red Gold' nectarines: Temperature-dependent effects on ethylene production and biosynthetic gene expression, fruit quality, and polyamine levels. Postharvest Biol. Tech. 37:111-121.

Calvo, G. and G.O. Sozzi. 2004. Improvement of postharvest storage quality of 'Red Clapps' pears by treatment with 1-methylcyclopropene at low temperature. J. Hort. Sci. Biotechnol. 79:930-934.

Cocozza, F.M., J.T. Jorge, R.E. Alves, H.A.C. Filgueiras, D. Santos, and M.E.C. Pereira. 2004. Sensory and physical evaluations of cold stored 'Tommy Atkins' mangoes influenced by 1-MCP and modified atmosphere packaging. Acta Hort. 645:655-661.

Colelli, G. and M.L. Amodio. 2003. Effetti delete trattamento con 1-MCP di frutti di actinidia interi e a fette. Frutticoltura 3:61-67.

Dal Cin, V., F.M. Rizzini, A. Botton, and P. Tonutti. 2006. The ethylene biosynthetic and signal transduction pathways are differently affected by 1-MCP in apple and peach fruit. Postharvest Biol. Tech. 42:125-133.

Dauny, P.T. and D.C. Joyce. 2002. 1-MCP improves storability of 'Queen Cox' and 'Bramley' apple fruit. HortScience 37:1082-1085.

DeEll, J.R., D.P. Murr, L. Wiley, and M.D. Porteous. 2003. 1-Methylcyclopropene (1-MCP) increases $\mathrm{CO}_{2}$ injury in apples. Acta Hort. 600:277-280.

de Lima, M.A.C., R.E. Alves, C.I. Biscegli, H.A.C. Filgueiras, and F.D.M. Cocozza. 2004. Conservacao pos-colheita de meloes Galia 'Solar King' tratados com 1-metilciclopropreno. Hort. Bras. 22:121-126.

DeLong, J.M., R.K. Prange, and P.A. Harrison. 2004. The influence of 1-methylcyclopropene on 'Cortland' and 'McIntosh' apple quality following long-term storage. HortScience 39:1062-1065.

de Martino, G., K. Vizovitis, R. Botondi, A. Bellincontro, and F. Mencarelli. 2006. 1-MCP controls ripening induced by impact injury on apricots by affecting SOD and POX activities. Postharvest Biol. Tech. 39:38-47.

Dong, L., S. Lurie, and H.W. Zhou. 2002. Effect of 1-methylcyclopropene on ripening of 'Canino' apricots and 'Royal Zee' plums. Postharvest Biol. Tech. 24:135-145.

Dong, L., H.W. Zhou, L. Sonego, A. Lers, and S. Lurie. 2001. Ethylene involvement in the cold storage disorder of 'Flavortop' nectarine. Postharvest Biol. Tech. 23:105-115.

Dou, H., S. Jones, and M. Ritenour. 2005. Influence of 1-MCP application and concentration on post-harvest peel disorders and incidence of decay in citrus fruit. J. Hort. Sci. Biotechnol. 80:786-792.

Ekman, J.H., M. Clayton, W.V. Biasi, and E.J. Mitcham. 2004. Interactions between 1-MCP concentration, treatment interval and storage time for 'Bartlett' pears. Postharvest Biol. Tech. 31:127-136.

Ergun, M., J. Jeong, D.J. Huber, and D.J. Cantliffe. 2005. Suppression of ripening and softening of 'Galia' melons by 1-methylcyclopropene applied at preripe or ripe stages of development. HortScience 40:170-175.

Fan, X., L. Argenta, and J.P. Mattheis. 2002. Interactive effects of 1-MCP and temperature on 'Elberta' peach quality. HortScience 37: $134-138$.

Fan, X. and J.P. Mattheis. 2000a. Reduction of ethylene-induced physiological disorders of carrots and iceberg lettuce by 1-methylcyclopropene. HortScience 35:1312-1314.

Fan, X.T., S.M. Blankenship, and J.P. Mattheis. 1999. 1-Methylcyclopropene inhibits apple ripening. J. Amer. Soc. Hort. Sci. 124:690-695.

Fan, X.T., J.P. Mattheis, and R.G. Roberts. 2000 Biosynthesis of phytoalexin in carrot root requires ethylene action. Physiol. Plant. 110: $450-454$.

Feng, X.Q., A. Apelbaum, E.C. Sisler, and R. Goren. 2000. Control of ethylene responses in avocado fruit with 1-methylcyclopropene. Postharvest Biol. Tech. 20:143-150.

Feng, X.Q., A. Apelbaum, E.C. Sisler, and R. Goren. 2004. Control of ethylene activity in various plant systems by structural analogues of 1-methylcyclopropene. Plant Growth Reg. 42:29-38.

Gal, S., S. Alkalai-Tuvia, Y. Elkind, and E. Fallik. 2006. Influence of different concentrations of 1-methylcyclopropene and times of exposure on the quality of 'Galia'-type melon harvested at different stages of maturity. J. Hort. Sci. Biotechnol. 81:975-982.

Girardi, C.L., A.R. Corrent, L. Lucchetta, M.R Zanuzo, T.S. da Costa, A. Brackmann, R.M. Twyman, F.R. Nora, L. Nora, J.A. Silva, and C.V. Rombaldi. 2005. Effect of ethylene, intermittent warming and controlled atmosphere on postharvest quality and the occurrence of woolliness in peach (Prunus persica cv. Chiripa) during cold storage. Postharvest Biol. Tech. 38:25-33.

Golding, J.B., D. Shearer, S.G. Wyllie, and W.B. McGlasson. 1998. Application of 1-MCP and propylene to identify ethylene-dependent ripening processes in mature banana fruit. Postharvest Biol. Tech. 14:87-98.

Gong, Y.P. and J.P. Mattheis. 2003. Effect of ethylene and 1-methylcyclopropene on chlorophyll catabolism of broccoli florets. Plant Growth Reg. 40:33-38.

Guillen, F., S. Castillo, P.J. Zapata, D. MartinezRomero, D. Valero, and M. Serrano. 2006 Efficacy of 1-MCP treatment in tomato fruit. 2. Effect of cultivar and ripening stage at harvest. Postharvest Biol. Tech. 42:235-242.

Harima, S., R. Nakano, S. Yamauchi, Y. Kitano, Y. Yamamoto, A. Inaba, and Y. Kubo. 2003. Extending shelf-life of astringent persimmon (Diospyros kaki Thunb.) fruit by 1-MCP. Postharvest Biol. Tech. 29:319-324.

Harker, F.R., J. Maindonald, S.H. Murray, F.A. Gunson, I.C. Hallett, and S.B. Walker. 2002. Sensory interpretation of instrumental measurements 1: Texture of apple fruit. Postharvest Biology Tech. 24:225-239.

Harris, D.R., J.A. Seberry, R.B.H. Wills, and L.J. Spohr. 2000. Effect of fruit maturity on efficiency of 1-methylcyclopropene to delay the ripening of bananas. Postharvest Biol. Tech. 20:303-308.

Hershkovitz, V., S.I. Saguy, and E. Pesis. 2005. Postharvest application of 1-MCP to improve the quality of various avocado cultivars. Postharvest Biol. Tech. 37:252-264.

Hofman, P.J., M. Jobin-Decor, G.F. Meiburg, A.J. Macnish, and D.C. Joyce. 2001. Ripening and quality responses of avocado, custard apple, mango and papaya fruit to 1-methylcyclopropene. Austral. J. Expt. Agr. 41:567572.

Hurr, B.M., D.J. Huber, and J.H. Lee. 2005. Differential responses in color changes and softening of 'Florida 47' tomato fruit treated at green and advanced ripening stages with the ethylene antagonist 1-methylcyclopropene. HortTechnology 15:617-622.

Janisiewicz, W.J., B. Leverentz, W.S. Conway, R.A. Saftner, A.N. Reed, and M.J. Camp. 2003. Control of bitter rot and blue mold of apples by integrating heat and antagonist treatments on 1-MCP treated fruit stored under controlled atmosphere conditions. Postharvest Biol. Tech. 29:129-143.

Jayanty, S.S., M. Canoles, and R.M. Beaudry. 2004. Concentration dependence of 'Redchief Delicious' apple fruit softening and chlorophyll fluorescence to repeated doses of 1-methylcyclopropene. J. Amer. Soc. Hort. Sci. 129:760-765.

Jeong, J., D.J. Huber, and S.A. Sargent. 2002. Influence of 1-methylcyclopropene (1-MCP) on ripening and cell-wall matrix polysaccharides of avocado (Persea americana) fruit. Postharvest Biol. Tech. 25:241-256.

Jiang, Y. and D.C. Joyce. 2000. Effects of 1-methylcyclopropene alone and in combination with polyethylene bags on the postharvest life of mango fruit. Ann. Appl. Biol. 137:321327.

Jiang, Y.M., D.C. Joyce, W.B. Jiang, and W.J. Lu. 2004. Effects of chilling temperatures on ethylene binding by banana fruit. Plant Growth Reg. 43:109-115.

Jiang, Y.M., D.C. Joyce, and A.J. Macnish. 1999. Responses of banana fruit to treatment with 1-methylcyclopropene. Plant Growth Reg. 28:77-82.

Jiang, Y.M., D.C. Joyce, and L.A. Terry. 2001 1-Methylcyclopropene treatment affects strawberry fruit decay. Postharvest Biol. Tech. 23:227-232

Kim, H.O., E.W. Hewett, and N. Lallu. 2001 Softening and ethylene production of kiwifruit reduced with 1-methylcyclopropene. Acta Hort. 553:167-170.

Krammes, J.G., C.A. Megguer, L.C. Argenta, C.V.T. Amarante, and D. Grossi. 2003. Uso do 1-metilciclopropeno para retardar a maturacao de tomate. Hort. Bras. 21:611-614.

$\mathrm{Ku}$, V.V.V. and R.B.H. Wills. 1999. Effect of 1-methylcyclopropene on the storage life of broccoli. Postharvest Biol. Tech. 17:127132.

$\mathrm{Ku}$, V.V.V., R.B.H. Wills, and S. Ben-Yehoshua. 1999. 1-Methylcyclopropene can differentially affect the postharvest life of strawberries exposed to ethylene. HortScience 34:119 120.

Kubo, Y., K. Hiwasa, W.O. Owino, R. Nakano, and A. Inaba. 2003. Influence of time and concentration of 1-MCP application on the shelf life of pear 'La France' fruit. HortScience 38: 1414-1416.

Kupferman, E. 2005. Consumer requirements for apples, p. 1-7. Proc. Apple Handling and Storage Workshop, Ithaca, NY.

Lalel, H.J.D., Z. Singh, and S.C. Tan. 2003 The role of ethylene in mango fruit aroma volatiles biosynthesis. J. Hort. Sci. Biotechnol. 78:485-496. 
Leverentz, B., W.S. Conway, W.J. Janisiewicz, R.A. Saftner, and M.J. Camp. 2003. Effect of combining MCP treatment, heat treatment, and biocontrol on the reduction of postharvest decay of 'Golden Delicious' apples. Postharvest Biol. Tech. 27:221-233.

Liguori, G., A. Weksler, Y. Zutahi, S. Lurie, and I. Kosto. 2004. Effect of 1-methylcyclopropene on ripening of melting flesh peaches and nectarines. Postharvest Biol. Tech. 31:263-268.

Liu, F.W. and M.M. King. 1978. Consumer evaluations of McIntosh apple firmness. HortScience 13:162-163.

Liu, H.X., W.B. Jiang, L.G. Zhou, B.G. Wang, and Y.B. Luo. 2005. The effects of 1-methylcyclopropene on peach fruit (Prunus persica L. cV. Jiubao) ripening and disease resistance. Intl. J. Food Sci. Tech. 40:1-7.

Luo, Z. 2007. Effect of 1-methylcyclopropene on ripening of postharvest persimmon (Diospyros kaki L.) fruit. LWT-Food Sci Tech. 40:285291.

Lurie, S., C. Pre-Aymard, U. Ravid, O. Larkov, and E. Fallik. 2002. Effect of 1-methylcyclopropene on volatile emission and aroma in cv. Anna apples. J. Agr. Food Chem. 50:42514256.

MacRae, E.A., N. Lallu, A.N. Searle, and J.H. Bowen. 1989. Changes in the softening and composition of kiwifruit affected by maturity at harvest and postharvest treatment. J. Sci. Food Agr. 49:413-430.

Mao, L.C., Y. Karakurt, and D.J. Huber. 2004a. Incidence of water-soaking and phospholipid catabolism in ripe watermelon (Citrullus lanatus) fruit: Induction by ethylene and prophylactic effects of 1-methylcyclopropene. Postharvest Biol. Tech. 33:1-9.

Mao, L.C., F. Que, and H.J. Donald. 2004b. 1-Methylcyclopropene and $\mathrm{CaCl}_{2}$ treatments affect lipolytic enzymes in fresh-cut watermelon fruit. Acta Bot. Sin. 46:1402-1407.

Marcos, J.F., L. Gonzalez-Candelas, and L. Zacarias. 2005. Involvement of ethylene biosynthesis and perception in the susceptibility of citrus fruits to Penicillium digitatum infection and the accumulation of defence-related mRNAs. J. Expt. Bot. 56:2183-2193.

Martinez-Romero, D., E. Dupille, F. Guillen, J.M. Valverde, M. Serrano, and D. Valero. 2003. 1-Methylcyclopropene increases storability and shelf life in climacteric and nonclimacteric plums. J. Agr. Food Chem. 51:4680-4686.

Menniti, A.M., R. Gregori, and I. Donati. 2004. 1-Methylcyclopropene retards postharvest softening of plums. Postharvest Biol. Tech. 31:269-275.

Minniti, A.M., R. Gregori, and I. Donati. 2005. Effect of 1-methylcyclopropene on kiwifruit softening. Acta Hort. 682:2095-2099.

Mir, N., M. Canoles, R. Beaudry, E. Baldwin, and C. Pal Mehla. 2004. Inhibiting tomato ripening with 1-methylcyclopropene. J. Amer. Soc. Hort. Sci. 129:112-120.

Mir, N.A., E. Curell, N. Khan, M. Whitaker, and R.M. Beaudry. 2001. Harvest maturity, storage temperature, and 1-MCP application frequency alter firmness retention and chlorophyll fluorescence of 'Redchief Delicious' apples. J. Amer. Soc. Hort. Sci. 126:618-624.

Moran, R.E. and P. McManus. 2005. Firmness retention, and prevention of coreline browning and senescence in 'Macoun' apples with 1-methylcyclopropene. HortScience 40: 161-163.

Mostofi, Y., P.M.A. Toivonen, H. Lessani, M. Babalar, and C.W. Lu. 2003. Effects of 1methylcyclopropene on ripening of greenhouse tomatoes at three storage temperatures. Postharvest Biol. Tech. 27:285-292.

Moya-Leon, M.A., M. Vergara, C. Bravo, M.E. Montes, and C. Moggia. 2006. 1-MCP preserves aroma quality of 'Packham's Triumph' pears during long term storage. Postharvest Biol. Tech. 42:185-197.

Mullins, E.D., T.G. McCollum, and R.E. McDonald. 2000. Consequences on ethylene metabolism of inactivating the ethylene receptor sites in diseased non-climacteric fruit. Postharvest Biol. Tech. 19:155-164.

Nakano, R., S. Inoue, Y. Kubo, and A. Inaba. 2002. Water stress-induced ethylene in the calyx triggers autocatalytic ethylene production and fruit softening in 'Tonewase' persimmon grown in a heated plastic-house. Postharvest Biol. Tech. 25:293-300.

Opiyo, A.M. and T.J. Ying. 2005. The effects of 1methylcyclopropene treatment on the shelf life and quality of cherry tomato (Lycopersicon esculentum var. cerasiforme) fruit. Int. J. Food Sci. Technol. 40:665-673.

Ortiz, G.I., S. Sugaya, Y. Sekozawa, H. Ito, K. Wada, and H. Gemma. 2005. Efficacy of 1-methylcyclopropene (1-MCP) in prolonging the shelf-life of 'Rendaiji' persimmon fruits previously subjected to astringency removal treatment. J. Japan Hort. Sci. 73: 248-254.

Pechous, S.W., C.B. Watkins, and B.D. Whitaker. 2005 . Expression of $\alpha$-farnesene synthase gene AFS1 in relation to levels of $\alpha$-farnesene and conjugated trienols in peel tissue of scaldsusceptible 'Law Rome' and scald-resistant 'Idared' apple fruit. Postharvest Biol. Tech. 35:125-132.

Pelayo, C., E.V.D. Vilas-Boas, M. Benichou, and A.A. Kader. 2003. Variability in responses of partially ripe bananas to 1-methylcyclopropene. Postharvest Biol. Tech. 28:75-85.

Pesis, E., M. Ackerman, R. Ben-Arie, O. Feygenberg, X.Q. Feng, A. Apelbaum, R. Goren, and D. Prusky. 2002. Ethylene involvement in chilling injury symptoms of avocado during cold storage. Postharvest Biol. Tech. 24:171-181.

Porat, R., B. Weiss, L. Cohen, A. Daus, R. Goren, and S. Droby. 1999. Effects of ethylene and 1-methylcyclopropene on the postharvest qualities of 'Shamouti' oranges. Postharvest Biol. Tech. 15:155-163.

Pre-Aymard, C., E. Fallik, A. Weksler, and S. Lurie. 2005. Sensory analysis and instrumental measurements of 'Anna' apples treated with 1methylcyclopropene. Postharvest Biol. Technol. 36:135-142.

Rudell, D.R., J.P. Mattheis, and J.K. Fellman. 2006. Influence of ethylene action, storage atmosphere, and storage duration on diphenylamine and diphenylamine derivative content of Granny Smith apple peel. J. Agr. Food Chem. 54:2365-2371.

Rupasinghe, H.P.V., D.P. Murr, G. Paliyath, and L. Skog. 2000. Inhibitory effect of 1-MCP on ripening and superficial scald development in 'McIntosh' and 'Delicious' apples. J. Hort. Sci. Biotechnol. 75:271-276.

Saftner, R.A., J.A. Abbott, W.S. Conway, and C.L. Barden. 2003. Effects of 1-methylcyclopropene and heat treatments on ripening and postharvest decay in 'Golden Delicious' apples. J. Amer. Soc. Hort. Sci. 128:120-127.

Saltveit, M.E. 1999. Effect of ethylene on quality of fresh fruits and vegetables. Postharvest Biol. Tech. 15:279-292.

Saltveit, M.E. 2004. Effect of 1-methylcyclopropene on phenylpropanoid metabolism, the accumulation of phenolic compounds, and browning of whole and fresh-cut 'iceberg' lettuce. Postharvest Biol. Tech. 34:75-80.

Salvador, A., J. Cuquerella, and J.M. MartinezJavega. 2003. 1-MCP treatment prolongs postharvest life of 'Santa Rosa' plums. J. Food Sci. 68:1504-1510.

Salvador, A., J. Cuquerella, J.M. Martinez-Javega, A. Monterde, and P. Navarro. 2004. 1-MCP preserves the firmness of stored persimmon 'Rojo Brillante'. J. Food Sci. 69:S69-S73.

Selvarajah, S., A.D. Bauchot, and P. John. 2001. Internal browning in cold-stored pineapples is suppressed by a postharvest application of 1-methylcyclopropene. Postharvest Biol. Tech. 23:167-170.

Sisler, E.C., M. Serek, and E. Dupille. 1996. Comparison of cyclopropene, 1-methylcyclopropene, and 3,3-dimethylcyclopropene as ethylene antagonists in plants. Plant Growth Reg. 18:169-174.

SmartFresh. 2006. Apple use recommendations. SmartFresh, AgroFresh, Inc., Philadelphia, PA.

Tay, S.L. and C.O. Perera. 2004. Effect of 1methylcyclopropene treatment and edible coatings on the quality of minimally processed lettuce. J. Food Sci. 69:C131-C135.

Toivonen, P.M.A. and C.W. Lu. 2005. Studies on elevated temperature, short-term storage of 'Sunrise' Summer apples using 1-MCP to maintain quality. J. Hort. Sci. Biotechnol. 80:439-446.

Trinchero, G.D., G.O. Sozzi, F. Covatta, and A.A. Fraschima. 2004. Inhibition of ethylene action by 1-methylcyclopropene extends postharvest life of 'Bartlett' pears. Postharvest Biol. Tech. 32:193-204.

Valero, D., D. Martinez-Romero, J.M. Valverde, F. Guillen, S. Castillo, and M. Serrano. 2004 Could the 1-MCP treatment effectiveness in plum be affected by packaging? Postharvest Biol. Tech. 34:295-303.

Valero, D., D. Martinez-Romero, J.M. Valverde, F. Guillen, and M. Serrano. 2003. Quality improvement and extension of shelf life by 1-methylcyclopropene in plum as affected by ripening stage at harvest. Innov. Food Sci. Emerg. Tech. I 4:339-348.

Vallejo, F. and R. Beaudry. 2006. Depletion of 1MCP by 'non-target' materials from fruit storage facilities. Postharvest Biol. Tech. 40:177182 .

Wang, B.G., W.B. Jiang, H.X. Liu, L. Lin, and J.H. Wang. 2006. Enhancing the post-harvest qualities of mango fruit by vacuum infiltration treatment with 1-methylcyclopropene. J. Hort. Sci. Biotechnol. 81:163-167.

Watkins, C.B. 2002. Ethylene synthesis, mode of action, consequences and control, p. 180-224. In: M. Knee (ed.). Fruit quality and its biological basis. Sheffield Academic Press, Boca Raton, FL.

Watkins, C.B. 2003. Principles and practices of postharvest handling and stress, p. 585-614. In: D. Feree and I.J. Warrington (eds.). Apples: Crop physiology, production and uses. CAB Publishing. Wallingford, Oxon, UK.

Watkins, C.B. 2006. The use of 1-methylcyclopropene (1-MCP) on fruits and vegetables. Biotechnol. Adv. 24:389-409.

Watkins, C.B. 2007. The effect of 1-MCP on the development of physiological storage disorders in horticultural crops. Stewart Postharvest Rev. $2: 11$.

Watkins, C.B. and J.H. Ekman. 2005. How postharvest technologies affect quality, p. 437-481. In: S. Ben-Yehoshua (ed.). Environmentally friendly technologies for agricutural produce quality. CRC Press., Boca Raton, FL. 
Watkins, C.B. and W.B. Miller. 2006. A summary of physiological processes or disorders in fruits, vegetables and ornamental products that are delayed or decreased, increased, or unaffected by application of 1-methylcyclopropene (1MCP). 28 Dec. 2006. <http://www.hort.cornell. $\mathrm{edu} / \mathrm{mcp} />$.

Watkins, C.B. and J.F. Nock. 2005. Effects of delays between harvest and 1-methylcyclopropene (1MCP) treatment, and temperature of treatment, on ripening of air- and controlled atmospherestored apples. HortScience 40:2096-2101.
Watkins, C.B., J.F. Nock, and B.D. Whitaker. 2000. Responses of early, mid and late season apple cultivars to postharvest application of 1-methylcyclopropene (1-MCP) under air and controlled atmosphere storage conditions. Postharvest Biol. Tech. 19:17-32.

Wills, R.B.H. and V.V.V. Ku. 2002. Use of 1-MCP to extend the time to ripen of green tomatoes and postharvest life of ripe tomatoes. Postharvest Biol. Tech. 26:85-90.

Wills, R.B.H., V.V.V. Ku, and M.A. Warton. 2002. Use of 1-methylcyclopropene to extend the postharvest life of lettuce. J. Sci. Food Agr. 82: 1253-1255.

Woolf, A.B., C. Requejo-Tapia, K.A. Cox, R.C. Jackman, A. Gunson, M.L. Arpaia, and A. White. 2005. 1-MCP reduces physiological storage disorders of 'Hass' avocados. Postharvest Biol. Tech. 35:43-60.

Zanella, A. 2003. Control of apple superficial scald and ripening-A comparison between 1-methylcyclopropene and diphenylamine postharvest treatments, initial low oxygen stress and ultra low oxygen storage. Postharvest Biol. Tech. 27:69-78. 